\title{
FAKTOR-FAKTOR YANG YANG MEMPENGARUH KECENDERUNGAN KECURANGAN (FRAUD): PERSEPSI PEGAWAI DINAS PEMERINTAH KOTA BANDAR LAMPUNG Muhammad Luthfi, Eko Wijoyo, Kusnadi
}

Program Studi Akuntansi, Fakultas Ekonomi, Universitas Malahayati

Jl. Pramuka No. 27 Kemiling, Bandar Lampung, Lampung, Telp: 0721271112, Fax: 27119

Email: mluthfi@malahayati.ac.id, 12ekowijoyo@gmail.com, kusnadi.msi@gmail.com

\begin{abstract}
The purpose of this study is to analyze the perception of government employees about the impact of asymetric information, enforcement of regulations, the effectiveness of internal control, unethical behaviour, compensation suitability, and leadership style to tendency of fraud in government sector. The population of this study is 110 employees who work at financial subsector on Dinas Kota Bandar Lampung. This study is a population research, therefore the respondents of this study are all of the population. The data were obtained by questionnaire. It's analyzed by using analyze tool smartPLS 3. The result of this study showes positive impact of asymetric information, enforcement of regulations, and unethical behaviour towards tendency of fraud on government sector, there is no impact between the effectiveness of internal control and compensation suitability towards tendency of fraud on government sector.
\end{abstract}

Key words : Asymetric infrmation, enforcement of regulations, effectiveness of internal control, unethical behaviour, compensation suitability, leadership style, government sector

\section{PENDAHULUAN}

Kecurangan atau fraud merupakan penipuan yang dibuat untuk mendapatkan keuntungan pribadi atau untuk merugikan orang lain atau suatu tindak kesengajaan untuk menggunakan sumber daya perusahaan secara tidak wajar dan salah menyajikan fakta untuk memperoleh keuntungan pribadi. Salah satu tindak kecurangan ( fraud) yang terjadi di Indonesia adalah korupsi. Beberapa survei indikator global menunjukkan bahwa korupsi menempati urutan pertama dalam laporan Global Competitiveness Index 2016-2017 oleh Wold Economic Forum dengan persentase 11,6\% kemudian disusul inefisiensi birokrasi menempati urutan kedua dengan persentase 9,3\% salah satu sumber inefisiensi dan sebagai faktor penghambat usaha di Indonesia. Bahkan data 2017 dari Indonesia Corruption Watch memperlihatkan aparat sipil menduduki urutan teratas sebagai pelaku korupsi, diikuti DPRD, dan kepala daerah. 
Jurnal Ilmiah Akuntansi Rahmaniyah (JIAR)

Vol. 2 No.1, Desember 2018, 19 - 31

Tabel 1

Daftar Tingkat Kasus Korupsi di Indonesia

\begin{tabular}{|c|c|c|}
\hline No & Tahun & Jumlah Kasus \\
\hline 1 & 2013 & 560 Kasus \\
\hline 2 & 2014 & 629 Kasus \\
\hline 3 & 2015 & 550 Kasus \\
\hline 4 & 2016 & 482 Kasus \\
\hline
\end{tabular}

Sumber : Indonesia Corruption Watch 2017

Tabel 2

Daftar kasus Fraud di Bandar Lampung

\begin{tabular}{|c|c|}
\hline No & Keterangan \\
\hline 1 & $\begin{array}{l}\text { Beberapa kasus korupsi yang terjadi adalah kasus korupsi } \\
\text { penyelewengan dana bantuan operasional sekolah (BOS) SMPN } 24 \\
\text { Bandar Lampung anggaran } 2013 \text { hingga 2015. Tersangka adalah } \\
\text { mantan Kepala Sekolah SMPN } 24 \text { Bandar Lampung Helendrasari dan } \\
\text { mantan bendahara SMPN } 24 \text { Bandar Lampung Ayu Septaria. Total } \\
\text { kerugian Negara diperkirakan sebesar Rp } 800 \text { juta. } \\
\text { Sumber : teraslampung.com }\end{array}$ \\
\hline 2 & $\begin{array}{l}\text { Kasus selanjutnya kasus korupsi pembangunan jalan kampung gudang } \\
\text { lelang pada Dinas Kelautan dan Perikanan (DKP) Bandar Lampung } \\
\text { 2012, menyebabkan kerugian Negara mencapai Rp } 345 \text { juta, terpidana } \\
\text { dalam kasus ini melibatkan Mansyur Sinaga mantan Kepala Dinas, } \\
\text { kemudian Sahaldi (Direktur CV Alma Semesta Abadi), Mursalim } \\
\text { (Pejabat Pembuat Komitmen), Ardian (Pengawas Pekerjaan) dan } \\
\text { Liones Wangsa (Owner Golden Dragon). } \\
\text { Sumber : tribunlampung.co.id }\end{array}$ \\
\hline 3 & $\begin{array}{l}\text { Serta kasus dugaan korupsi pengadaan lima unit ambulans dan } \\
\text { sejumlah mobil kesehatan keliling dari dinas kesehatan (Diskes) } \\
\text { Provinsi Lampung anggaran 2012, tersangka yaitu berinisial WA dan } \\
\text { HP dan keduanya diduga telah merugikan negara sebesar Rp } 8 \text { miliar. } \\
\text { Sumber : jejamo.com }\end{array}$ \\
\hline
\end{tabular}

Faktor yang menyebabkan maraknya tindak kecurangan akuntansi salah satunya adalah, asimetri informasi. Selain asimetri informasi, penegakan peraturan juga merupakan faktor yang mempengaruhi tindak kecurangan. Di dalam suatu instansi baik pemerintah maupun swasta tindak kecurangan masih banyak terjadi, antara lain dikarenakan lemahnya penegakan peraturan. Wilopo (2006) menegaskan, untuk mendapatkan hasil yang monitoring yang baik, maka diperlukan pengendalian internal yang efektif. Pengendalian intern merupakan suatu kebijakan dan prosedur yang melindungi aktiva perusahaan dari kesalahan penggunaan, memastikan bahwa informasi usaha yang disajikan akurat dan meyakinkan bahwa hukum serta peraturan telah diikuti. Perilaku tidak etis muncul karena karyawan merasa tidak puas dan kecewa dengan hasil yang di dapat dari 
perusahaan serta lemahnya pengawasan manajemen yang dapat membuka keleluasaan karyawan untuk melakukan tindakan yang dapat merugikan perusahaan. Selain faktor-faktor yang telah diuraikan sebelumnya, kesesuaian kompensasi juga merupakan salah satu faktor yang mempengaruhi kecenderungan kecurangan. Kompensasi acapkali juga disebut penghargaan dan dapat didefinisikan sebagai setiap bentuk penghargaan yang diberikan kepada karyawan sebagai balas jasa atas kontribusi yang mereka berikan kepada organisasi. Dengan kompensasi yang sesuai, kecurangan akuntansi dapat berkurang. Faktor selanjutnya yaitu gaya kepemimpinan seorang pemimpin. Jabatan, tanggung jawab, maupun otoritas memberikan peluang risiko fraud. Maju mundurnya suatu organisasi tergantung seberapa baik pemimpin dapat memainkan perannya agar organisasi itu terus hidup dan berkembang. Sudibyo (2016).

Penelitian ini merupakan replikasi penelitian dari Mustika, dkk. (2016). Pada penelitian tersebut meneliti tentang kecenderungan kecurangan (fraud) di Dinas Pemerintah Kabupaten Way Kanan dengan variabel yang terkait yaitu asimetri informasi, penegakan peraturan, keefektifan pengendalian internal, perilaku tidak etis dan kesesuaian kompensasi. Pada penelitian ini adanya penambahan variabel yaitu variabel gaya kepemimpinan. Hasil penelitian Mustika, dkk. (2016) menunjukkan bahwa asimetri informasi tidak berpengaruh terhadap kecenderungan kecurangan (fraud), penegakan peraturan berpengaruh terhadap kecenderungan kecurangan (fraud), keefektifan pengendalian internal tidak berpengaruh terhadap kecenderungan kecurangan (fraud), perilaku tidak etis berpengaruh terhadap kecenderungan kecurangan (fraud), dan kesesuaian kompensasi tidak berpengaruh terhadap kecenderungan kecurangan (fraud). Sampel dalam penelitian ini adalah pegawai eselon III sampai dengan eselon V subbagian keuangan di Dinas Pemerintah Kota Bandar Lampung. Tujuan penelitian ini adalah untuk menganalisis kembali dengan menggunakan variabel yang berbeda, lokasi penelitian yang berbeda dan alat analisis yang berbeda. Penelitian ini ingin menguji pengaruh asimetri informasi, penegakan peraturan, keefektifan pengendalian internal, perilaku tidak etis, kesesuaian kompensasi, dan gaya kepemimpinan terhadap kecenderungan kecurangan (fraud) pada sektor pemerintahan Dinas kota Bandar Lampung. Berdasarkan latar belakang diatas, penulis tertarik untuk melakukan penelitian dengan judul : "Faktor-faktor yang Mempengaruhi Kecenderungan Kecurangan (fraud): Persepsi Pegawai Dinas Pemerintah Kota Bandar Lampung”.

\section{LANDASAN TEORI}

\section{The Fraud Diamond Theory}


Theory Fraud Diamond merupakan teori yang menjadi dasar atau latar belakang untuk seseorang dalam melakukan kecurangan. Wolfe dan Hermanson dalam Sari (2016). Fraud Diamond menambahkan komponen kemampuan (Capability) setelah 3 komponen yang terdapat dalam Fraud triangle Theory yang dikemukakan oleh Cressey (1973) yaitu pembenaran (rationalization), tekanan (pressure), dan kesempatan (opportunity).

\section{Teori Atribusi}

Menurut Waworuntu (2003) teori atribusi yaitu teori yang tidak terlepas dari perilaku seseorang dalam organisasi, yaitu perilaku pimpinan dan perilaku bawahan. Kepemimpinan tidak terlepas dari cara berpikir, berperasaan, bertindak, bersikap, dan berperilaku dalam kerja di sebuah organisasi dengan bawahannya atau orang lain.

\section{Kecurangan (Fraud)}

Menurut the Association of Certified Fraud Examiners (ACFE) dalam Najahningrum (2013), kecurangan merupakan perbuatan-perbuatan yang melawann hukum yang dilakukan dengan sengaja untuk tujuan tertentu (manipulasi atau memberikan laporan keliru terhadap pihak lain) dilakukan orang orang dari dalam atau luar organisasi untuk mendapatkan keuntungan pribadi ataupun kelompok yang secara langsung atau tidak langsung merugikan pihak lain.

\section{Asimetri Informasi}

Asimetri informasi adalah suatu kondisi di mana ada ketidakseimbangan perolehan informasi antara pihak pemegang amanah (pemerintah daerah/eksekutif) sebagai penyedia informasi/agent dengan pihak pemberi amanah (masyarakat, perwakilan rakyat, dan legislatif) sebagai pengguna informasi/Principal (Scott, 2009).

\section{Penegakan Peraturan}

Penegakan peraturan merupakan suatu usaha untuk mewujudkan ide-ide tentang keadilan, kepastian peraturan dan kemanfaatan sosial menjadi kenyataan. Proses perwujudan ide-ide itulah yang merupakan hakikat dari penegakan peraturan (Rahardjo, 2009).

\section{Keefektifan Pengendalian Internal}


Menurut Mulyadi (2008) Sistem Pengendalian Internal adalah suatu proses yang dijalankan oleh dewan komisaris, manajemen, dan personel lain, yang didesain untuk memberikan keyakinan memadai tentang pencapaian tiga golongan tujuan yakni kendala pelaporan keuangan, kepatuhan terhadap hukum dan peraturan yang berlaku, efektivitas dan efisiensi operasi.

\section{Perilaku Tidak Etis}

Buckley, dkk. (1998) dalam Wilopo (2006) menjelaskan bahwa perilaku tidak etis merupakan sesuatu yang sulit untuk dimengerti, yang jawabannya tergantung pada interaksi yang kompleks antara situasi serta karakteristik pribadi pelakunya.

\section{Kesesuaian Kompensasi}

Kompensasi merupakan semua pendapatan yang berbentuk uang, barang, langsung atau tidak langsung yang diterima karyawan sebagai imbalan atas jasa yang diberikan kepada perusahaan (Hasibuan, 2008).

\section{Gaya Kepemimpinan}

Menurut Sudibyo (2016) Kepemimpinan merupakan kemampuan mempengaruhi orang lain, bawahan atau kelompok, kemampuan mengarahkan tingkah laku bawahan atau kelompok, memiliki kemampuan atau keahlian khusus dalam bidang yang diinginkan oleh kelompoknya untuk mencapai tujuan organisasi atau kelompok.

\section{METODOLOGI PENELITIAN}

\section{Populasi}

Menurut Sugiyono (2013) populasi adalah wilayah generalisasi yang terdiri atas: obyek/subyek yang mempunyai kualitas dan karakteristik yang ditetapkan oleh peneliti untuk dipelajari dan kemudian ditarik kesimpulannya. Populasi dalam penelitian ini adalah pegawai negeri sipil eselon III sampai dengan eselon V subbagian keuangan yang bekerja di Dinas Pemerintah kota Bandar Lampung dengan jumlah 22 instansi yang terdiri dari kasubag, bendahara dan staf keuangan lainnya berjumlah 110 orang.

\section{Sampel}


Menurut Sugiyono (2013) Sampel adalah bagian dari jumlah dan karakteristik yang dimiliki oleh populasi tersebut. Sampel pada penelitian ini adalah populasi sama dengan sampel berjumlah 110 orang menggunakan sampling jenuh atau sensus.

\section{Metode Analisis Data}

Metode analisis data yang digunakan dalam penelitian ini analisis data menggunakan pendekatan Smart Partial Least Square (PLS). Terdiri dari Statistik Deskriptif, Model Pengukuran (Uji Validitas, Uji Realibilitas), Model Struktural (Coefficient of Determinan, Path Coefficient), dan Uji Hipotesis.

\section{HASIL DAN PEMBAHASAN}

\section{Statistik Deskriptif}

Penelitian ini bertujuan untuk membuktikan apakah faktor-faktor asimetri informasi, penegakan peraturan, keefektifan pengendalian internal, perilaku tidak etis, kesesuian kompensasi dan gaya kepemimpinan berpengaruh terhadap kecenderungan kecurangan (fraud) di Dinas Pemerintah Kota Bandar Lampung. Objek dalam penelitian ini adalah seluruh Dinas kota Bandar Lampung yang berjumlah 23 instansi, akan tetapi hanya 22 instansi yang memperoleh surat izin penyebaran kuisioner. Responden dalam penelitian ini adalah pegawai negeri sipil eselon III sampai dengan eselon V subbagian keuangan yang terdiri dari kasubag, bendahara, dan staf keuangan lainnya. Jumlah kuisioner yang disebar adalah 110 eksemplar. Jumlah kuisioner tersebut merupakan hasil survei awal yang bersedia dijadikan responden dalam penelitian. Dari 110 kuisioner tersebut, yang kembali 108 kuisioner. Dari 108 kuisioner yang kembali, 100 kuisioner yang dapat diolah dan sisanya 8 kuisioner tidak dapat diolah karena data yang diisi tidak lengkap dan banyaknya pertanyaan yang tidak diisi. Hasil uji analisis deskriptif dari 100 data yang bisa diolah dapat dilihat bahwa responden seluruh sampel didominasi oleh laki-laki sebanyak 56 orang atau $56 \%$ sedangkan sisanya 44 orang atau $44 \%$ dari responden perempuan, Berdasarkan tingkat usia responden lebih banyak berada diusia 31-40 tahun dengan jumlah 70 orang atau $70 \%$ pada usia 20-30 tahun berjumlah 11 orang atau $11 \%$ dan pada usia $>40$ tahun berjumlah 19 orang atau $19 \%$. Berdasarkan tabel 4.3 dapat dilihat bahwa responden yang memiliki usia jenjang pendidikan paling banyak adalah strata 1 yaitu 69 orang atau 69\% sisanya strata 2 berjumlah 21 orang atau 21\% dan SMA/D3 berjumlah 10 orang atau $10 \%$. Berdasarkan dari masa pengalaman kerja responden yang memiliki 
Jurnal Ilmiah Akuntansi Rahmaniyah (JIAR)

Vol. 2 No.1, Desember 2018, $19-31$

lama masa bekerja paling banyak adalah > 5 tahun dengan jemlah 59 orang atau $59 \%$ sedangkan yang memiliki lama masa bekerja paling sedikit adalah $<1$ tahun dengan jumlah 2 orang atau $2 \%$.

\section{Outer Model (Model Pengukuran)}

\section{Uji Validitas}

\section{AVE}

Hasil dalam validitas convergent dihitung dengan melihat output construct reliability and validity yang didalamnya terdapat nilai AVE. Kriteria nilai validitas convergent dikatakan baik jika memiliki nilai AVE lebih dari 0,5. Berdasarkan tabel dibawah ini masing-masing variabel memiliki nilai diatas 0,5 . Hal ini dapat diartikan bahwa konstrak memiliki nilai convergent yang baik.

Tabel 3

Nilai AVE

\begin{tabular}{|l|c|}
\hline & $\begin{array}{c}\text { Average Variance } \\
\text { Extracted (AVE) }\end{array}$ \\
\hline Asimetri Informasi & 0.760 \\
\hline Gaya Kepemimpinan & 0.643 \\
\hline Kecenderungan Kecurangan & 0.591 \\
\hline Keefektifan Pengendalian Internal & 0.619 \\
\hline Kesesuaian Kompensasi & 0.592 \\
\hline Penegakan Peratauran & 0.617 \\
\hline Perilaku Tidak Etis & 0.678 \\
\hline
\end{tabular}

Sumber: Data diolah 2017

\section{Validitas Diskriminan}

\section{a. Nilai Cross Loading}

Tabel 4 Nilai Cross Loading

\begin{tabular}{|l|l|l|l|l|l|l|l|}
\hline & $\begin{array}{l}\text { asimetri } \\
\text { informas } \\
\text { i }\end{array}$ & $\begin{array}{l}\text { gaya } \\
\text { kepemi } \\
\text { mpinan }\end{array}$ & $\begin{array}{l}\text { Kcndrun } \\
\text { gan } \\
\text { kecuran } \\
\text { gan }\end{array}$ & $\begin{array}{l}\text { keefektif } \\
\text { an } \\
\text { pengend } \\
\text { alian } \\
\text { internal }\end{array}$ & $\begin{array}{l}\text { kesesuaia } \\
\text { kmpensas } \\
\text { i }\end{array}$ & $\begin{array}{l}\text { penegaka } \\
\text { n } \\
\text { peraturan }\end{array}$ & $\begin{array}{l}\text { perilak } \\
\text { u tidak } \\
\text { etis }\end{array}$ \\
\hline AI1 & 0.842 & -0.306 & 0.269 & -0.228 & -0.218 & -0.128 & 0.140 \\
\hline AI2 & 0.929 & -0.207 & 0.162 & -0.131 & -0.246 & -0.058 & 0.059 \\
\hline AI3 & 0.893 & -0.077 & 0.161 & -0.120 & -0.120 & -0.040 & 0.039 \\
\hline AI4 & 0.861 & -0.217 & 0.120 & -0.188 & -0.158 & -0.229 & 0.155 \\
\hline
\end{tabular}


Jurnal Ilmiah Akuntansi Rahmaniyah (JIAR)

Vol. 2 No.1, Desember 2018, 19-31

Lutfi

\begin{tabular}{|c|c|c|c|c|c|c|c|}
\hline AI5 & 0.811 & -0.142 & 0.089 & -0.077 & -0.172 & -0.041 & 0.016 \\
\hline AI6 & 0.890 & -0.106 & 0.222 & -0.124 & -0.093 & -0.121 & 0.051 \\
\hline GP1 & -0.163 & 0.919 & -0.274 & 0.491 & 0.424 & 0.391 & -0.375 \\
\hline GP2 & -0.167 & 0.915 & -0.332 & 0.513 & 0.453 & 0.387 & -0.333 \\
\hline GP3 & -0.283 & 0.785 & -0.148 & 0.456 & 0.379 & 0.502 & -0.254 \\
\hline GP4 & -0.098 & 0.712 & -0.119 & 0.334 & 0.254 & 0.491 & -0.430 \\
\hline GP5 & -0.326 & 0.639 & -0.038 & 0.281 & 0.480 & 0.471 & -0.243 \\
\hline KK2 & 0.078 & -0.106 & 0.563 & -0.168 & 0.059 & -0.202 & 0.086 \\
\hline KK3 & 0.191 & -0.270 & 0.732 & -0.151 & -0.257 & -0.147 & 0.206 \\
\hline KK4 & 0.064 & -0.107 & 0.804 & -0.194 & -0.046 & -0.157 & 0.286 \\
\hline KK5 & 0.113 & -0.286 & 0.837 & -0.194 & -0.191 & -0.095 & 0.355 \\
\hline KK6 & 0.015 & -0.208 & 0.789 & -0.201 & -0.288 & -0.160 & 0.381 \\
\hline KK7 & 0.258 & -0.242 & 0.776 & -0.021 & -0.176 & -0.084 & 0.259 \\
\hline KK8 & 0.244 & -0.300 & 0.881 & -0.361 & -0.197 & -0.139 & 0.542 \\
\hline KK9 & 0.260 & -0.134 & 0.729 & -0.140 & -0.124 & -0.050 & 0.384 \\
\hline KKS1 & -0.301 & 0.391 & -0.150 & 0.208 & 0.808 & 0.211 & -0.369 \\
\hline KKS2 & -0.237 & 0.258 & 0.010 & 0.134 & 0.641 & 0.372 & -0.317 \\
\hline KKS3 & 0.025 & 0.511 & 0.013 & 0.302 & 0.686 & 0.487 & -0.248 \\
\hline KKS4 & -0.070 & 0.437 & -0.212 & 0.228 & 0.913 & 0.308 & -0.277 \\
\hline KPI1 & -0.028 & 0.241 & -0.108 & 0.599 & 0.090 & 0.479 & -0.311 \\
\hline KPI2 & -0.317 & 0.542 & -0.268 & 0.864 & 0.268 & 0.403 & -0.550 \\
\hline KPI3 & -0.075 & 0.449 & -0.168 & 0.883 & 0.175 & 0.279 & -0.364 \\
\hline KPI4 & -0.018 & 0.437 & -0.183 & 0.888 & 0.214 & 0.499 & -0.436 \\
\hline KPI5 & 0.119 & 0.230 & 0.017 & 0.650 & 0.108 & 0.392 & -0.389 \\
\hline PP1 & 0.057 & 0.237 & -0.097 & 0.478 & 0.165 & 0.684 & -0.367 \\
\hline PP2 & -0.201 & 0.285 & -0.041 & 0.265 & 0.181 & 0.754 & -0.317 \\
\hline PP3 & -0.096 & 0.491 & -0.186 & 0.447 & 0.249 & 0.932 & -0.415 \\
\hline PP4 & -0.191 & 0.424 & -0.052 & 0.180 & 0.333 & 0.654 & -0.325 \\
\hline PP5 & -0.176 & 0.459 & -0.090 & 0.414 & 0.269 & 0.867 & -0.406 \\
\hline PTE1 & 0.099 & -0.370 & 0.306 & -0.417 & -0.462 & -0.305 & 0.771 \\
\hline PTE2 & -0.017 & -0.103 & 0.420 & -0.393 & -0.133 & -0.147 & 0.749 \\
\hline PTE3 & 0.066 & -0.336 & 0.344 & -0.471 & -0.207 & -0.497 & 0.833 \\
\hline PTE4 & 0.170 & -0.426 & 0.422 & -0.523 & -0.334 & -0.513 & 0.891 \\
\hline PTE5 & 0.076 & -0.432 & 0.360 & -0.363 & -0.386 & -0.476 & 0.863 \\
\hline
\end{tabular}

Sumber: Data diolah 2017

Pada tabel 4 terlihat kolerasi AI1, AI2, AI3, AI4, AI5, dan AI6 dengan konstrak asimetri informasi adalah $0.842,0.929,0.893,0.861,0.811,0.890$. Nilai kolerasi konstrak lebih tinggi dengan konstrak asimetri informasi daripada nilai kolerasi konstrak lainnya. Demikian halnya dengan indikator- 
indikator lainnya yang menunjukkan berkolerasi lebih tinggi dengan masing-masing konstraknya, hal ini berarti bahwa memiliki discriminant validity yang baik.

\section{b. Perbandingan Nilai Kuadrat Kolerasi}

Tabel 5 Latent Variabel Correlations

\begin{tabular}{|c|c|c|c|c|c|c|c|}
\hline & $\begin{array}{l}\text { Asime } \\
\text { tri } \\
\text { Infor } \\
\text { masi }\end{array}$ & $\begin{array}{c}\text { Gaya } \\
\text { Kepemi } \\
\text { mpinan }\end{array}$ & $\begin{array}{c}\text { Kecen } \\
\text { derung } \\
\text { an } \\
\text { Kecur } \\
\text { angan }\end{array}$ & $\begin{array}{l}\text { Keefekti } \\
\text { fan } \\
\text { Pengend } \\
\text { alian } \\
\text { Internal }\end{array}$ & $\begin{array}{l}\text { Kesesuai } \\
\text { an } \\
\text { Kompen } \\
\text { sasi }\end{array}$ & $\begin{array}{c}\text { Penegaka } \\
\text { n } \\
\text { Peraturan }\end{array}$ & $\begin{array}{c}\text { Perilaku } \\
\text { Tidak } \\
\text { Etis }\end{array}$ \\
\hline $\begin{array}{l}\text { Asimetri } \\
\text { Informasi }\end{array}$ & 0.872 & & & & & & \\
\hline $\begin{array}{l}\text { Gaya } \\
\text { Kepemimpinan }\end{array}$ & -0.213 & 0.802 & & & & & \\
\hline $\begin{array}{l}\text { Kecenderungan } \\
\text { Kecurangan }\end{array}$ & 0.220 & -0.285 & 0.769 & & & & \\
\hline $\begin{array}{l}\text { Keefektifan } \\
\text { Pengendalian } \\
\text { Internal }\end{array}$ & -0.178 & 0.541 & -0.244 & 0.787 & & & \\
\hline $\begin{array}{l}\text { Kesesuaian } \\
\text { Kompensasi }\end{array}$ & -0.193 & 0.475 & -0.226 & 0.248 & 0.769 & & \\
\hline $\begin{array}{l}\text { Penegakan } \\
\text { Peraturan }\end{array}$ & -0.121 & 0.495 & -0.147 & 0.489 & 0.290 & 0.785 & \\
\hline $\begin{array}{l}\text { Perilaku Tidak } \\
\text { Etis }\end{array}$ & 0.095 & -0.399 & 0.457 & -0.529 & -0.360 & -0.468 & 0.823 \\
\hline
\end{tabular}

Sumber: Data diolah 2017

Pada tabel 5 diatas terlihat kolerasi maksimal konstrak asimetri informasi dengan konstrak lainya adalah 0.872 , kolerasi konstrak lainnya yaitu gaya kepemimpinan 0.802 , kecenderungan kecurangan 0.769, keefektifan pengendalian internal 0.787 , kesesuaian kompensasi 0.769 , penegakan peraturan 0.785, dan perilaku tidak etis 0.823. Konstrak diatas memiliki nilai akar AVE lebih tinggi dibandingkan dengan kolerasi antar konstrak lainnya.

\section{Uji Realibilitas}

Tabel 6 Quality Criteria (Composite Reliability, Cronbach's Alpha)

\begin{tabular}{|l|c|c|}
\hline & Cronbach's Alpha & Composite Reliability \\
\hline Asimetri Informasi & 0.940 & 0.950 \\
\hline Gaya Kepemimpinan & 0.875 & 0.898 \\
\hline Kecenderungan Kecurangan & 0.904 & 0.920 \\
\hline Keefektifan Pengendalian Internal & 0.858 & 0.888 \\
\hline Kesesuaian Kompensasi & 0.851 & 0.850 \\
\hline Penegakan Peratauran & 0.854 & 0.888 \\
\hline Perilaku Tidak Etis & 0.880 & 0.913 \\
\hline
\end{tabular}


Sumber: Data diolah 2017

Dari tabel diatas terlihat kontrak asimetri informasi memiliki nilai cronbach's alpha 0,940 dan composite reliability 0,950 , diatas 0,7 hal ini berarti konstrak dikatakan realibel. Konstrak lainnya menunjukkan cronbach's alpha dan compotite reliability juga telah memenuhi syarat kriteria untuk dikatakan realibel karena memiliki nilai diatas 0,7 .

\section{Coeffiicient Determination $\left(\mathbf{R}^{2}\right)$}

Tabel 7 R Square

\begin{tabular}{|l|l|}
\hline \multicolumn{1}{|c|}{ Independen variabel } & \multicolumn{1}{|c|}{$\mathbf{R}^{\mathbf{2}}$} \\
\hline Asimetri Informasi & \\
\cline { 1 - 1 } Gaya Kepemimpinan & \\
\cline { 1 - 1 } Kecenderungan Kecurangan & \\
\hline Keefektifan Pengendalian Internal & \\
\hline Kesesuaian Kompensasi & \\
\hline Penegakan Peratauran & \\
\hline Perilaku Tidak Etis & \\
\hline
\end{tabular}

Sumber: Data diolah 2017

Berdasarkan tabel 7 menunjukkan bahwa nilai $\mathrm{R}^{2}$ konstrak kecenderungan kecurangan adalah 0,265. Artinya konstrak asimetri informasi, penegakan peraturan, keefektifan pengendalian internal, perilaku tidak etis, kesesuaian kompensasi, dan gaya kepemimpinan mampu berkontribusi dan menjelaskan variabel konstrak kecenderungan kecurangan sebesar $26.5 \%$, sisanya $73.5 \%$ diterangkan oleh konstrak lainnya diluar yang diteliti.

\section{Path Coefficient}

Pada tabel 8 variabel yang menunjukkan adanya hubungan yang positif adalah asimetri informasi dengan nialai 0,167 , penegakan peraturan dengan nilai 0,150 , perilaku tidak etis dengan nilai 0,472 , untuk variabel gaya kepemimpinan mempunyai hubungan negatif dengan nilai $-0,161$, akan tetapi untuk variabel keefektifan pengendalian internal dan kesesuaian kompensasi tidak memiliki hubungan atau tidak berpengaruh terhadap kecenderungan kecurangan (fraud)

Tabel 8

PLS Structural Model (Path Coefficient, T Statistik)

\begin{tabular}{|c|c|c|c|c|c|c|c|}
\hline & & & $\begin{array}{c}\text { Original } \\
\text { Sample } \\
(0)\end{array}$ & $\begin{array}{c}\text { Sample } \\
\text { Mean (M) }\end{array}$ & $\begin{array}{l}\text { Standard } \\
\text { Deviation } \\
\text { (STDEV) }\end{array}$ & $\begin{array}{c}\text { T Statistics } \\
(|\mathrm{O} / \mathrm{STDEV}|)\end{array}$ & $\begin{array}{c}\mathbf{P} \\
\text { Values }\end{array}$ \\
\hline Asimetri & Informasi & $->$ & 0.167 & 0.179 & 0.097 & 1.712 & 0.087 \\
\hline
\end{tabular}


Jurnal Ilmiah Akuntansi Rahmaniyah (JIAR)

Vol. 2 No.1, Desember 2018, 19 - 31

Lutfi

\begin{tabular}{|l|c|c|c|c|c|}
\hline Kecenderungan Kecurangan & & & & & \\
\hline $\begin{array}{l}\text { Gaya Kepemimpinan -> } \\
\text { Kecenderungan Kecurangan }\end{array}$ & -0.161 & -0.142 & 0.124 & 1.299 & 0.195 \\
\hline $\begin{array}{l}\text { Keefektifan Pengendalian } \\
\text { Internal -> Kecenderungan } \\
\text { Kecurangan }\end{array}$ & 0.050 & 0.050 & 0.126 & 0.395 & 0.693 \\
\hline $\begin{array}{l}\text { Kesesuaian Kompensasi -> } \\
\text { Kecenderungan Kecurangan }\end{array}$ & -0.004 & 0.043 & 0.207 & 0.017 & 0.986 \\
\hline $\begin{array}{l}\text { Penegakan Peraturan -> } \\
\text { Kecenderungan Kecurangan }\end{array}$ & 0.150 & 0.047 & 0.154 & 0.976 & 0.329 \\
\hline $\begin{array}{l}\text { Perilaku Tidak Etis -> } \\
\text { Kecenderungan Kecurangan }\end{array}$ & 0.472 & 0.432 & 0.125 & 3.772 & 0.000 \\
\hline
\end{tabular}

Sumber: Data diolah 2017

*** Signifikan at $1 \%(2,364)=$ Sangat Signifikan

** Signifikan at $5 \%(1,660)=$ Signifikan

* Signifikan at $10 \%(1,290)=$ Signifikan lemah

\section{PEMBAHASAN}

Hipotesis yang diolah dengan menggunakan smartPLS yang menguji faktor-faktor yang mempengaruhi kecenderungan kecurangan (fraud): persepsi pegawai dinas pemerintah kota Bandar Lampung. Hasil analisis terlihat bahwa asimetri informasi, penegakan peraturan, perilaku tidak etis, mempunyai pengaruh signifikan terhadap kecenderungan kecurangan (fraud), gaya kepemimpinan mempunyai pengaruh negatif terhadap kecenderungan kecurangan (fraud), keefektifan pengendalian internal dan penegakan peraturan tidak berpengaruh terhadap kecenderungan kecurangan (fraud.

\section{SIMPULAN}

Berdasarkan hasil pengujian menggunakan metode analisis smartPLS 3 dalam penelitian ini, maka dapat diambil kesimpulan sebagai berikut :

1. Hasil penelitian menunjukkan bahwa asimetri informasi berpengaruh signifikan terhadap kecenderungan kecurangan (fraud). Dengan kata lain, semakin tinggi asimetri informasi, maka semakin tinggi pula tingkat kecurangan kecurangan (fraud).

2. Hasil penelitian menunjukkan bahwa penegakan peraturan berpengaruh terhadap kecenderungan kecurangan (fraud). Dengan kata lain, lemahnya penegakan peraturan dalam suatu instansi, maka akan membuka peluamg pegawai untuk melakukan tindakan kecuranagan artinya penegakan peraturan dapat menekan terjadinya kecurangan (fraud). 
3. Hasil penelitian menunjukkan bahwa keefektifan pengendalian internal tidak berpengaruh terhadap kecenderungan kecurangan (fraud) sehingga dapat diambil kesimpulan bahwa keefektifan pengendalian internal tidak dapat menekan terjadinya kecurangan (fraud).

4. Hasil penelitian menunjukkan bahwa perilaku tidak etis berpengaruh sangat signifikan terhadap kecenderungan kecurangan (fraud). Dengan kata lain, semakin rendah perilaku tidak etis yang dilakukan oleh pegawai dalam suatu instansi maka semakin rendah pula kemungkinan terjadinya kecurangan.

5. Hasil penelitian menunjukkan bahwa kesesuaian kompensasi tidak berpengaruh terhadap kecenderungan kecurangan (fraud) sehingga dapat diambil kesimpulan bahwa kesesuaian kompensasi tidak dapat menekan terjadinya kecurangan (fraud).

6. Hasil penelitian menunjukkan bahwa gaya kepemimpinan berpengaruh negatif terhadap kecenderungan kecurangan (fraud). Dengan kata lain, semakin tinggi gaya kepemimpinan, semakin rendah kemungkinan terjadinya kecurangan artinya gaya kepemimpinan yang baik dapat menekan terjadinya kecuranagan (fraud).

\section{DAFTAR PUSTAKA}

Accounting Media. (2017). Diakses di www.accountingmedia.com pada 3 maret 2017 Pukul 20.00 WIB.

Ghozali, Imam. (2008). Structural Equation Modeling Metode Alternatif dengan Parsial Least Square (PLS). Semarang : Undip

http://www.jejamo.com/kejati-lampung-tahan-dua-tersangka-kasus-korupsi-pengadaanambulans-dinkes-provinsi-lampung.html. Di akses pada 3 Maret 2017 pukul 20.00 WIB.

http://lampung.tribunnews.com/2016/06/27/jaksa-tetap-bidik-kasus-dugaan-korupsi-pabrikes-rp-17-m-di-dkp. Di akses pada 3 Maret 2017 pukul 20.00 WIB. https://www.teraslampung.com/korupsi-dana-bos-mantan-kepsek-smpn-24bandarlampung-dan-bendahara-divonis-ringan/. Di akses pada 3 Maret 2017 pukul 20.00 WIB. 
Indonesia Corruption Watch (ICW). (2016). Diakses di www.Infokorupsi.com pada 3 Maret 2017 Pukul 20.00 WIB.

Mulyadi. (2008). Auditing. Edisi Keenam. Jakarta: Salemba Empat.

Mustika, Dian, Hastuti, Sri, Heriningsih. (2016). Analisis Faktor-faktor yang Mempengaruhi Kecenderungan Kecurangan (Fraud): Persepsi Dinas Kabupaten Way Kanan Lampung. Simposium Nasional Akuntansi XIX, Lampung.

Najahningrum, Anik Fatun. (2013) Faktor-Faktor yang Mempengaruhi Fraud: Persepsi Pegawai Dinas Provinsi DIY. Universitas Negeri Semarang: Accounting Analysis Journal. ISSN 2252-6765.

Sari, Deviana. (2016). Analisis Faktor-faktor yang mempengaruhi terjadinya kecurangan

(Fraud) di sektor pemerintahan kota Bandar Lampung: persepsi pegawai pemerintahan. Tesis. Fakultas Ekonomi Universitas Lampung.

Scott, William R. (2009). Financial Accounting Theory. Fifth Edition. Canada: Prentice Hall.

Sudibyo, Tyagita Dianingtyas. (2016). Pengaruh Gaya Kepemimpinan dan Budaya Organisasi Terhadap Efektivitas Sistem Pengendalian Internal Dalam Mendeteksi Risiko Fraud di PT. Kaltim Industrial Estate. Tesis. Fakultas Ekonomi Universitas Sanata Dharma.

Sugiyono. (2013). Metode Penelitian Bisnis. Bandung: CV. Alfabeta.

Rahardjo, Satjipto. (2009). Penegakan Hukum suatu tinjauan sosiologis. Yogyakarta: Genta Publishing.

Waworuntu, Bob. (2003). Determinan Kepemimpinan. Makalah Sosial Humaniora, vol.7, no. 2, Desember 2003.

Wilopo. (2006). Analisis Faktor-faktor yang Berpengaruh Terhadap Kecenderungan Kecurangan Akuntansi: Studi pada Perusahaan Publik dan Badan Usaha Milik Negara di Indonesia. Simposium Nasional Akuntansi (SNA) IX Padang. 